\title{
The Dynamic History of the Ophthalmology Residency Matching Program
}

\author{
Christopher F. Blodi, MD ${ }^{1}$ Ronald R. Krueger, $\mathrm{MD}^{1}$
}

Address for correspondence Christopher F. Blodi, MD, Department of Ophthalmology, Truhlsen Eye Institute, University of Nebraska Medical Center, 3902 Leavenworth Street Omaha, NE 68105 (e-mail: cblodiirc@gmail.com).

\begin{abstract}
Keywords

- ophthalmology residency match

- graduate medical education

- history of ophthalmology

Background The ophthalmology residency matching program is the first successful medical specialty match, dating back to 1979 . This article reviews the impetus for starting the match and the roles that ophthalmologists Bruce Spivey, MD, and August Colenbrander, $\mathrm{MD}, \mathrm{PhD}$, played in establishing the match and developing the machinery to make it possible. Challenges to the match's operations over the years have improved the process.

Objective This article aims to research the roles of key individuals and institutions in establishing and maintaining the ophthalmology residency matching program.

Methods Oral and written interviews with key participants in establishing and maintaining the match were conducted. Primary and secondary written materials were reviewed.

Results Two physicians played key roles in establishing the ophthalmology residency matching program. Bruce Spivey, MD, spearheaded the drive to persuade the Association of University Professors of Ophthalmology (AUPO) to support and sponsor the match. August Colenbrander, MD, PhD, created the original match algorithm and single-handedly ran the match process in the early years. Obstacles were overcome, including resistance from the Association of American Medical College's National Resident Matching Program, a challenge to the validity of the algorithm, and the threat that antitrust laws might prohibit all graduate medical education residency match programs. The ophthalmology match evolved over time to become a more formal entity, the San Francisco Matching Program (SF Match). With continued support of the AUPO, the process of matching applicants to residency programs has flourished despite contemporary challenges related to electronic applications and social media.

Conclusion The ophthalmology residency matching program has benefited applicants and teaching programs for more than four decades due to visionary founders, ongoing support of the AUPO, and strong leadership within SF Match.
\end{abstract}

received

September 1, 2021 accepted after revision October 12, 2021
DOI https://doi.org/ $10.1055 / \mathrm{s}-0041-1741468$. ISSN 2475-4757.

\footnotetext{
(C) 2022. The Author(s).

This is an open access article published by Thieme under the terms of the Creative Commons Attribution-NonDerivative-NonCommercial-License, permitting copying and reproduction so long as the original work is given appropriate credit. Contents may not be used for commercial purposes, or adapted, remixed, transformed or built upon. (https://creativecommons.org/ licenses/by-nc-nd/4.0/) Thieme Medical Publishers, Inc., 333 Seventh Avenue, 18th Floor, New York, NY 10001, USA
} 
In 1977, the Association of University Professors of Ophthalmology (AUPO) voted to sponsor a program to match medical student applicants to ophthalmology resident positions. This program was intended to supplement the National Residency Matching Program (NRMP), originally called the National Internship Matching Program, that began in 1953. While the history of the NRMP has been well-documented, no such review exists for the ophthalmology residency matching program (ophthalmology match). Exploring this evolution reveals a fascinating history of what contemporary medical students know as the San Francisco Matching Program (SF Match). Hurdles were overcome to initiate the process, obstacles were navigated in the early years, and ongoing refinements to the ophthalmology match continue to benefit training programs and applicants alike.

Oral and written interviews were conducted with leaders who were instrumental in establishing the ophthalmology match in 1979, Bruce E. Spivey, MD, and August Colenbrander, MD, PhD; past presidents of the AUPO, Frederick T. Fraunfelder, MD, and Robert E. Kalina, MD; SF Match director Timothy R. Losch; AUPO Program Directors Council member Misha Syed, MD; retina specialist James C. Folk, MD, who began his residency before the ophthalmology match was established; and an ophthalmologist successfully trained through the match, Christy Benson, MD. Primary and secondary written materials were reviewed. Some information is not publicly available, such as meeting minutes from AUPO and SF Match. Additionally, early SF Match data was saved onto a computer disc in a format that is not currently accessible.

\section{Discussion}

\section{Early Years before the Ophthalmology Match (1916-1979)}

Until 1979, the method used by ophthalmology departments to select new resident trainees had remained unchanged since ophthalmology graduate medical education began. Applicants contacted programs at any point during their medical school years. Programs would interview students and offer positions that would commence two, three, or even more years later. These positions would be contingent upon the applicant first graduating from medical school and completing an internship, after which ophthalmic training as a postgraduate year (PGY) 2 physician would begin. For some, the lengthy span between offer and start date related to military obligations to be fulfilled after medical school. But over time, it became apparent that junior and even sophomore medical students were being offered postgraduate positions. The offers frequently included expiration dates, colloquially known as "exploding offers," whereby the applicant had a limited amount of time to accept or decline. It was not unheard of for an offer to be valid for only a few days, or even less.

Applicants were therefore faced with the option of accepting an offer, or declining and hoping that a better offer might be extended later. Retina specialist James C. Folk, MD, recalls securing a residency offer from Pittsburgh Eye and Ear (now
University of Pittsburgh Medical Center, Eye and Ear Institute) in the prematch era when he was a fourth year medical student: "I applied in the fall of 1976 and got an immediate interview because they had an opening. They offered a spot at the end of the interview" (email, February 8, 2021). Folk accepted the offer without applying to, or interviewing with, any other residency programs (J.C. Folk, MD, email, February 8, 2021).

\section{Establishment of NRMP in 1953 Becomes Model for Ophthalmology Match}

The process for obtaining ophthalmology residency positions prior to 1979 mirrored the process for internship positions before 1953. In that year, the Association of American Medical Colleges (AAMC) instituted a matching program to pair applicants with internships, with a process that offered structure and fairness to applicants and programs alike.

The compelling origin story of the NRMP has been welldocumented. ${ }^{1-3}$ Briefly, the AAMC proposed a matching algorithm that was tested for one application cycle; but when the algorithm was introduced, medical students rebelled. ${ }^{3,4}$ Led by W. Hardy Hendren III of Harvard University, the students asserted that the algorithm favored the programs substantially. ${ }^{4}$ A nationwide committee of medical students developed a better matching algorithm, which the AAMC accepted and used thereafter. ${ }^{4}$

The NRMP has been a model for the ophthalmology match. Since the NRMP's inception in 1953, many developments have improved graduate medical education. For example, the Medicare Act of 1965 markedly increased graduate medical education spending., ${ }^{5,6}$ Additionally, the formation of the American Board of Ophthalmology (ABO) in 1916, with its work establishing standards and certifications for trainees, has promoted excellence in the field of ophthalmology. ${ }^{7}$ Most important was the $\mathrm{ABO}$ requirement that, to become Board certified, a doctor must devote a specified period of time solely to ophthalmic graduate medical education. $^{8}$

\section{The 1962 Gale-Shapley Matching Algorithm}

In 1962, economists David Gale, PhD, and Lloyd Shapley, PhD, described an algorithm for matching entities from two groups equitably as an attempt to solve the "stable matching problem." ${ }^{\prime}$ They did this unaware that the NRMP had, for many years, already been performing matches according to the work they theorized. ${ }^{10}$ When the economists later learned of this, they agreed that the NRMP had already utilized this type of matching. ${ }^{11}$ In 2012, Shapley and colleague Alvin Roth of Harvard University received the Nobel Prize in economics for work on matching algorithm development, Gale having died in 2008. ${ }^{10}$

Ophthalmology Match Founded by Bruce Spivey, MD, and August Colenbrander, MD, PhD (1979)

Ophthalmologist Bruce Spivey, MD (-Fig. 1), was instrumental in founding the ophthalmology match. Born in 1934 in Cedar Rapids, Iowa, Spivey's training included medical school and residency at the University of Iowa, a pediatric 


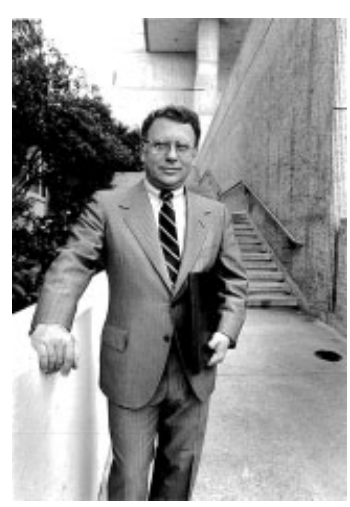

Fig. 1 Bruce E. Spivey, MD, in the early 1970s (photo with permission of Bruce Spivey, MD).

ophthalmology fellowship and a Master's in Education degree from the University of Illinois. Spivey went on to become chairman of the ophthalmology department at Pacific Medical Center (now California Pacific Medical Center) in San Francisco in 1971. In his capacity as ophthalmology department chairman, Spivey was able to attend meetings of the AUPO, which at the time limited membership to include only department heads.

Spivey realized, in discussions with other department leaders, that the resident selection system had drawbacks limiting both programs and medical students. Applicants were pressured to commit to a career in ophthalmology early in their medical school years, to forgo other options, and to take the "bird in the hand" offer. Programs were pressured to extend offers early, to attract high-quality students. This timetable often made it difficult to evaluate the professional potential of inexperienced students who were barely entering their clinical years. At that time, the AUPO concentrated on improving the resident selection process, yet never considered a matching program.

Awareness of these limitations motivated Spivey to work, over the course of several years, to persuade a majority of department leaders that a matching program would be prudent. The structure would include interviewing rising senior medical students early in autumn. Students would generate a rank order list of programs that they wished to attend, and programs would create a list of students they would be willing to have as residents. The two lists would then be processed through a matching algorithm. The goal was to match each student with the program they ranked highest that wished to have them as residents. This would be accomplished well before the NRMP match so that applicants could make suitable plans for their PGY-1 year, or alternate career plans, if they failed to match into an ophthalmology program.

The proposed ophthalmology match was initially met with pushback from some ophthalmology residency programs. Programs considered more prestigious thought that a match system would diminish their prominence by leveling the differences in status among programs. Programs that were smaller or considered less prestigious also feared being disadvantaged, concerned that students would only apply to larger programs. Spivey and others worked hard to convince all programs of the benefits. These included being able to assess candidates' abilities more accurately as rising seniors, further along in their studies at the time of selection than under the traditional system. Spivey also noted that there had always been more candidates than positions nationwide, which would allow smaller and lesser-known programs to draw from a larger pool of candidates. He told the larger, better-known programs that if they were truly strong departments, then they would have no problems filling their residency slots with excellent applicants: "You should be able to recruit against the smaller programs" Spivey recalled telling them (oral communication, February 16, 2021). Frederick T. Fraunfelder, MD, who served as AUPO president during this time, recalled that persuading uncertain department heads to support the ophthalmology match was best done at the AUPO annual meetings, usually in smaller, private conversations during social events (oral communication, March 4, 2021).

In the fall of 1977, the AUPO voted to sponsor a matching program to begin the following year, for students graduating in the spring of $1979 .{ }^{12}$ Spivey recalls that the vote was far from unanimous, "not even 90\%" (oral communication, February 16,2021 ), but that all programs elected to participate once the majority vote determined that the ophthalmology match would be established. The fact that there were more small programs and that these supported the match helped get the idea approved. Spivey oversaw the ophthalmology match while ophthalmologist August "Gus" Colenbrander, MD, PhD (-Fig. 2), created the matching algorithm and served as program coordinator. ${ }^{12}$

Colenbrander, an ophthalmology colleague of Spivey at Pacific Medical Center, had a background in mathematics and computing, ideal for the development of a matching algorithm. Colenbrander was born in 1931 and raised in Leiden, the Netherlands, where his father was Professor and chair of the ophthalmology department. Colenbrander completed medical school at Leiden University, the Netherlands, in 1959, later completing his residency in ophthalmology and receiving his $\mathrm{PhD}$ at Utrecht University in $1964 .{ }^{13}$ When asked by his department chief to work on a new disease coding system, Colenbrander put the information on punch cards and learned about computers, cutting-edge technology for the 1960s.

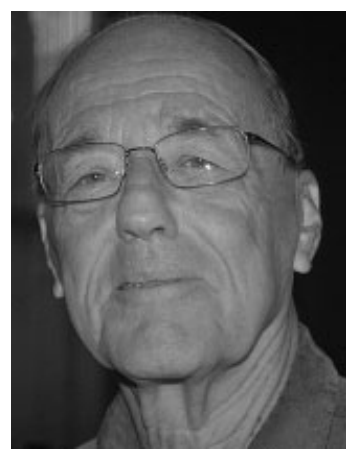

Fig. 2 August Colenbrander, MD, PhD, in 2016 (photo with permission of the Department of Ophthalmology, California Pacific Medical Center). 
Colenbrander gave a talk about this work at a European ophthalmology meeting where he met Spivey, who invited him to tour U.S. ophthalmology departments including his own at the time, at the University of Iowa. This led to Colenbrander becoming a visiting Professor at the University of Iowa beginning in 1969, and then relocating permanently to the United States with his wife and two children. In 1971, when Spivey became chair at Pacific Medical Center, Colenbrander moved to San Francisco as well, working at Pacific Medical Center for more than 25 years, specializing in low vision and becoming director of the Vision Rehabilitation service. $^{13}$

Colenbrander, a gifted mathematician, was the ideal candidate to serve as program coordinator for the ophthalmology match and develop its matching algorithm. He developed the algorithm on his own, saying that he had never read about or in any way studied either the NRMP match or Shapley's game theory. Colenbrander said that it was simply an "iterative process"; he had never before thought of residency selection or matching strategies (oral communication, February 10, 2021). The original code was a "spaghetti code" but was later switched to a more stable Structured Query Language (SQL) code (A. Colenbrander, MD, $\mathrm{PhD}$, oral communication, February 10, 2021).

The first ophthalmology matches were performed manually by Colenbrander, who enlisted the help of several Pacific Medical Center departmental secretaries. This was tedious work: as the assistants could only tolerate the work for a few hours a day, it took several weeks to complete. While neither Spivey nor Pacific Medical Center received any money from the AUPO for this work, eventually "Gus got some money" (B.E. Spivey, MD, oral communication, February 16, 2021). The money, Colenbrander recalled, came from Pacific Medical Center (oral communication, February 10, 2021).

\section{Early Years of the Ophthalmology Match}

The first years of the ophthalmology match went quite smoothly. All accredited programs participated, with few complaints and no ill-will. Spivey felt that it "helped that ophthalmology was and is a collegial field" (oral communication, February 16, 2021). Colenbrander recalled that a few programs attempted a work-around whereby they submitted rank order lists with the same number of applicant names as positions available, and that those applicants submitted rank order lists naming only that one particular program. This seemed like an obvious attempt by the program to circumvent the match by promising those applicants a position, clearly beyond the spirit of the match. Spivey and other AUPO members held private discussions with those department leaders to persuade them to "play by the rules" (B.E. Spivey, MD, oral communication, February 10, 2021).

It helped that from the very beginning, there were more applicants than positions. While the AUPO thought that the ratio would be approximately 2 to $3: 1$, Colenbrander recalled it actually being closer to $1.5: 1$ (oral communication, February 10,2021 ). In these early years, Colenbrander would call programs with some unfilled positions and ask them to add more names to their rank order list. Colenbrander also made sure to present data each year at the annual AUPO meeting. He recalled that "people liked that I came to the AUPO and talked to them about how the match worked. I wasn't the chairman so I wasn't a threat to anyone. Bruce (Spivey) did the politics, I did the match" (oral communication, February 10,2021 ).

\section{AAMC Effort in the 1980s to have NRMP Take over Ophthalmology Match}

The ophthalmology match has encountered several obstacles since inception. Robert E. Kalina, MD, who served as AUPO president in the early years of the ophthalmology match, recalled that the AAMC routinely asked for the AUPO to relinquish authority over the ophthalmology match to the NRMP (oral communication, March 18, 2021). Spivey attended AAMC meetings and recalled "getting a lot of sniping from them" about the ophthalmology match (oral communication, February 16, 2021). For instance, at their September 1983 meeting, the AAMC board discussed in detail their desire to usurp control over the ophthalmology match. ${ }^{14}$

\section{0s' Ophthalmology Match Algorithm Challenge Prompts Change}

A second early obstacle came in the form of objections to the actual match algorithm. In 1981, Kevin Jon Williams, MD, then an internal medicine resident at the University of Chicago, realized that both the NRMP and the ophthalmology match algorithms slightly favored the program over the applicant. ${ }^{15}$ This was a subtle mathematical issue. Williams spent many years attempting to publish his observation so that it would gain recognition by the NRMP. A series of articles, first in the New England Journal of Medicine in 1981 and 15 years later in Academic Medicine. It was only after the latter publication, in 1996, that Colenbrander learned of the issue and reviewed his own algorithm. He realized that it did indeed slightly favor the programs. ${ }^{16,17}$ Colenbrander immediately changed the algorithm for the ophthalmology match to slightly favor the applicant, something that the NRMP did not do for some time. ${ }^{18}$

Colenbrander recalled that he reevaluated the prior 5 years of the match with the new algorithm to see if the old and new algorithms produced different results; his reevaluation demonstrated that only a few subtle changes would have occurred (A. Colenbrander, MD, PhD, oral communication, February 10, 2021). Colenbrander thought that the NRMP was slow to change because "they didn't have people who fully understood programming" (A. Colenbrander, MD, PhD, oral communication, February 10, 2021).

\section{Ophthalmology Match Survives 2002 Antitrust Challenge}

In 2002, a threat to the ophthalmology match loomed when a group of Family Medicine residents filed a lawsuit against the AAMC, claiming that the NRMP violated antitrust laws. ${ }^{19,20}$ While the ophthalmology match was not a party to the suit, it was clear that a judicial ruling dissolving the NRMP would 
set a precedent applicable to the ophthalmology match, which would be halted.

At the heart of this class action lawsuit, Jung $v$ Association of American Medical Colleges, ${ }^{19}$ were allegations that the NRMP imposed anticompetitive restraints on medical residents in violation of the federal antitrust laws embodied in the Sherman Act. ${ }^{19-24}$ The plaintiffs alleged that the AAMC required medical students to use the NRMP to obtain graduate medical education and, concomitantly, accept offers, wages, and working conditions without appropriate ability to negotiate terms $^{22}$; limited overall U.S. training positions; limited residents' abilities to transfer employment to a different program; and allowed programs to share information and enter into agreements that allowed them to keep residents' salaries low and in some instances, suppress the right to negotiate. ${ }^{19-24}$

Drs. Kalina and Spivey monitored the lawsuit carefully due to their relationships with the AAMC. At that time, Spivey was president of the Council of Medical Specialty Societies which was "very afraid of the suit" (B.E. Spivey, MD, oral communication, February 16, 2021). Many legal experts expected the plaintiffs to prevail in court on the theory that the NRMP violated antitrust principles of the federal Sherman Act by entering into collusive agreements that suppressed competition regarding residents' salaries and hours. ${ }^{22}$ Other legal analysts envisaged that the context of medical education and professional tradition might impact the case, and argued for a legislative solution; indeed, the antitrust laws themselves contemplate exemptions. ${ }^{20,22}$

A fortuitous, serendipitous event led to just such a legislative solution. W. Hardy Hendren, III, MD, who had led the initial battle to establish a more fair internship match as a medical student in 1953, was now a renowned pediatric surgeon at Harvard University. Hendren and a colleague happened to meet their state's senior U.S. Senator Ted Kennedy one weekend on the Boston docks after they had all been sailing. The two physicians explained the dilemma to Senator Kennedy and extolled the virtues of the NRMP. ${ }^{4}$

Shortly thereafter, Kennedy and Senator Judd Gregg of New Hampshire undertook a federal legislative initiative to protect the NRMP. ${ }^{19,23,25}$ Specifically, the Senators added a rider to an unrelated federal spending bill, the Pension Funding Equity Act of 2004, expressly stating that the NRMP was exempt from the antitrust law, and that, moreover, such exemption was to be retroactive. ${ }^{23,25}$ Some objected to the rider on the basis that it had not been adequately debated. ${ }^{23}$

The bill, with the attached rider, was signed into law by President George W. Bush in April of 2004. ${ }^{25}$ The lawsuit against the NRMP was dismissed shortly thereafter, in August of 2004, with the court ruling that the recently enacted federal legislation exempted the NRMP, and all graduate medical education programs, from the antitrust law claims. ${ }^{19}$ As such, the validity of the NRMP was assured by federal legislation $^{25}$ and confirmed by the judicial ruling. ${ }^{19,24}$

\section{The San Francisco Residency and Fellowship Matching Services (SF Match)}

In the early 1990s the matching process became more formalized as the San Francisco Residency and Fellowship
Matching Services organization (T.R. Losch, CMP, email, August 2, 2021). This organization, and the ophthalmology residency and fellowship match program it administers, are each known as "SF Match." ${ }^{26}$ The program is now considered an affiliate of the American Academy of Ophthalmology (AAO) and is run out of the AAO office. SF Match has an executive committee composed of ophthalmologists from the AUPO and SF Match director Timothy R. Losch, CMP (T.R. Losch, CMP, oral communication, April 1, 2021). The SF Match sees the AUPO as a "client" and these two organizations work together closely, continuously striving to improve the matching process (T.R. Losch, CMP, oral communication, April 1, 2021). For example, in 1985, ophthalmology fellowships were added to the ophthalmology residency matching program. Later in the 1980 s, the introduction of a common application eliminated the need for applicants to complete unique forms for each program. In the 1990s, the match began to embrace digital technology that streamlined the ophthalmology match application process and was less reliant on paper-based methods. ${ }^{12}$ SF Match engaged Xerox to develop a computer program to register documents submitted by applicants as they arrived. By 2011, the entire process was completed online. The application, the submission of the rank order list, and the results were now performed electronically. For the first year of the online process, the plan to simultaneously email all applicants their match results on the posted date ended with a failure of the SF Match email system (T.R. Losch, CMP, oral communication, April 1, 2021). Applicants, such as Christy Benson, MD, anxiously awaited emails that never came (Christy Benson, MD, oral communication, March 5, 2021). Later that day, the match results were sent via the traditional system: a FAX to each medical school's Dean's office from which the results could be relayed to the applicants (T.R. Losch, CMP, oral communication, April 1, 2021).

\section{Contemporary Trends and Future Directions}

In recent years, the matching process has met challenges and opportunities related to life in the Internet era. Social media now allows students everywhere to communicate with each other via online forums or communities such as those found on Reddit, Twitter, Facebook, or other digital platforms. Now, applicants may easily share information and impressions about residency programs in a manner not traditionally possible.

For many years, SF Match has made statistical information publicly available shortly after each year's results were known. This includes information such as number of applicants; number of positions; average number of applications per position; average number of interviews per applicant; average U.S. Medical Licensing Examination (USMLE) step one score of successful and unsuccessfully matched candidates; and the percentage of those matched who received their first choice, second choice, third choice (and so on) program. This information created a situation whereby applicants knew that not all would find a position, and that increasing the number of programs one applied to might increase the odds of success. 
As a result of this information and online discussions about the increasingly intense competition for limited positions, the number of programs applied to per applicant soared. For example, in 1994, 639 applicants applied to 442 available positions, with the average applicant applying to 41 residency programs. ${ }^{27}$ In 2021, 677 applicants applied to 499 available positions, with the average applicant applying to 79 residency programs. The average USMLE step one score of matched applicants, often used by programs as an initial device to screen applicants, had risen from 228 in 1994 to 245 in $2021 .^{26}$ By creating a common application, the SF Match had simplified the task of the applicant who could now easily apply to as many programs as desired simply by paying a modest fee to do so.

Some observers note that, at least in the more general NRMP, simply increasing the number of programs applied to did not materially increase the odds of matching into a desired program. ${ }^{28}$ Moreover, the increase in the number of programs applied to per applicant, a phenomenon known as "overapplication," increases the workloads of departments, which may need to screen hundreds of applications to select a manageable number for interviews. Nevertheless, many applicants feel compelled to apply to many programs and accept as many interviews as possible, a time-consuming and costly endeavor, particularly given the constraints of typical medical students.

In recent years, the AUPO and SF Match have continued to work closely together. The AUPO has a "Match Oversight Committee" that interacts extensively with SF Match. While no residents or medical students sit on the committee, the AUPO conducts detailed surveys of selected applicants to gain data on their experiences with the match and entire application process, according to Misha Syed, MD, AUPO Program Directors Council member (oral communication, March 24, 2021).

The COVID-19 pandemic forced changes to the application system for the 2021 ophthalmology match. In-person interviews were discontinued and replaced with virtual video interviews. To prevent applicants from monopolizing the limited interview spots available, SF Match, in conjunction with the AUPO, set a limit of 20 interviews per applicant, with SF Match coordinating interview scheduling. As the results of this new system seemed agreeable to most applicants and programs, it was continued for an additional year. Whether or not this system will stay in place is unknown, although the rising proportion of digital natives as physicians and increasing role of technology suggest that as the match continues to evolve, it will embrace digital trends. ${ }^{29}$

SF Match also administers a residency match for plastic surgery and numerous fellowship matches in ophthalmology, otolaryngology, anesthesiology, and other fields. ${ }^{26}$ Future directions for the ophthalmology match may include a couples match, analogous to that of the NRMP, which would allow married couples or other partners to seek residency programs in the same geographic area. ${ }^{30}$ Others have suggested using a slightly different algorithm, claiming that doing so would improve match results for both applicants and programs. ${ }^{31}$
The success of the ophthalmology match is indeed laudable. Several specialties tried to establish matching programs in the 1960s but did not succeed, most notably psychiatry ${ }^{32}$ and pediatrics. These failed soon after initiation, mainly due to a lack of full cooperation by the departments. ${ }^{33}$ As such, the success of the ophthalmology match as the first successful specialty medicine match stands as a notable achievement that has benefitted programs and applicants alike. Today, the ophthalmology match is thriving, offering broad access to applicants nationwide, promoting geographic and demographic diversity among medical residents. The ophthalmology match continues to have a significant impact on the field of ophthalmology by promoting excellence in graduate medical education.

\section{Conclusion}

In summary, the compelling history of the ophthalmology residency matching program reveals elements that contributed to its status as the first successful medical specialty match. The founders and leaders responded to challenges and opportunities by remaining dedicated to excellence in ophthalmic training and affording applicants access to all programs. Perhaps only the foundation of the ABO with its work on requiring graduate medical education in ophthalmology, establishing standards and certification for trainees, and the Medicare Act of 1965 which markedly increased graduate medical education funding, have been more important.

\section{Funding}

None.

\section{Conflict of Interest}

Dr. Krueger is Chair of a Department of Ophthalmology that has a residency training program that could be affected by the information in the article.

\section{Acknowledgment}

The authors acknowledge the assistance of Daniel Bennett for his medical writing, literature research, and editorial work.

\section{References}

1 Mullin FJ, Stalnaker JM. The matching plan for internship appointment. J Med Educ 1951;26(05):341-346

2 Stalnaker JM. The matching program for intern placement. J Med Educ 1953;28(11):13-20

3 Roth AE. The origins, history, and design of the resident match. JAMA 2003;289(07):909-912

4 Nakayama DK, Hendren WH III. The 1951 Harvard student uprising against the intern match. Surgery 2017;161(06):1728-1734

51965 Social Security Act (Senate Report No. 404, Pt. 1, 89th Congress, 1st Sess. 36 [1965]; H.R. No. 213, 89th Cong., 1st Sess. 32 [1965])

6 Iglehart JK. Support for academic medical centers-revisiting the 1997 Balanced Budget Act. N Engl J Med 1999;341(04):299-304

7 Shaffer RN. The History of the American Board of Ophthalmology 1916-1991. Rochester, MN: Johnson Printing Co.; 1991:30-31 
8 Anderson ST, Nora LM, McEntee CW, Fitzgerald ME, Nugent SG. The history, role, and value of public directors on certifying boards: the American Board of Ophthalmology experience. Ophthalmology 2016;123(9, Suppl):S36-S39

9 Gale D, Shapley LS. College admissions and the stability of marriage. Am Math Mon 1962;69(01):9-15

10 Ball P. A Nobel for the art of matchmaking. Nature 2012. Doi: 10.1038/nature.2012.11607

11 Roth AE. The evolution of the labor market for medical interns and residents: a case study in game theory. J Polit Econ 1984; 92:991-1016

12 About AUPO. History. Association of University Professors of Ophthalmology website. Accessed July 15, 2021 at: https:// aupo.org/about-aupo/history

13 People: Research Staff. The Smith-Kettlewell Eye Research Institute website. Accessed July 15, 2021 at: https://www.ski.org/users/august-colenbrander

14 Association of American Medical Colleges. Organization of Student Representatives (OSR) Administrative Board Meeting Minutes. Washington, DC; September 21, 1983;1-2. Accessed July 19, 2021 at: https://www.aamc.org/media/18246/download

15 Williams KJ, Werth VP, Wolff JA. An analysis of the resident match. N Engl J Med 1981;304(19):1165-1166

16 National resident matching program. N Engl J Med 1981;305(09): 525-526

17 Colenbrander A. National Resident Matching Program. Examining the NRMP algorithm. Acad Med 1996;71(04):309-312

18 Roth AE, Peranson E. National Resident Matching Program. The effects of the change in the NRMP matching algorithm. JAMA 1997;278(09):729-732

19 Jung $v$ Association of American Medical Colleges, 339 F Supp 2d 26 (DDC 2004).

20 Miller FH, Greaney TL. National Resident Matching Program. The National Resident Matching Program and antitrust law. JAMA 2003;289(07):913-918

21 Sherman Antitrust Act, 15 USC section 1 (1890).
22 Bierig JR. Jung v. Association of American Medical Colleges: the lawsuit challenging our system of graduate medical education. J Am Coll Radiol 2004;1(01):40-47

23 Madison K. The residency match: competitive restraints in an imperfect world. Houst Law Rev 2005;42(03):759-836

24 Weinmeyer R. Challenging the medical residency matching system through antitrust litigation. AMA J Ethics 2015;17(02): 149-153

25 Pension Funding Equity Act of $2004 \S 207$, Pub L No. 108-218, 118 Stat 596 (2004) (codified at 15 U.S.C. § 37b). Accessed October 31, 2021 at: http://www.gpo.gov/fdsys/pkg/PLAW-108publ218/pdf/PLAW-108publ218.pdf

26 Ophthalmology Residency. San Francisco Residency and Fellowship Match Services website. Accessed July 15, 2021 at: https:// sfmatch.org/SpecialtyInsideAll.aspx? id=6\&typ $=2 \&$ name $=0$ phthalmology\#

27 Ophthalmology: Eye Physicians \& Surgeons Forum. The Student Doctor Network website. Accessed July 25, 2021 at: https:// forums.studentdoctor.net/threads/match-stats-are-out.101586/

28 Weissbart SJ, Kim SJ, Feinn RS, Stock JA. Relationship between the number of residency applications and the yearly match rate: time to start thinking about an application limit? J Grad Med Educ 2015;7(01):81-85

29 Venincasa MJ, Steren B, Young BK, et al. Ophthalmology residency match in the Covid-19 era: applicant and program director perceptions of the 2020-2021 application cycle. Semin Ophthalmol 2021;(04):1-6

30 Couples in the Match. The National Resident Matching Program website. Accessed July 15, 2021 at: https://www.nrmp.org/couples-in-the-match/

31 Wu Y, Lee CS, Lee AY, Van Gelder RN. Algorithmic optimization of residency matching for a win-win outcome. Invest Ophthalmol Vis Sci 2021;62(08):2648

32 Barchilon J, Darley W. National psychiatric residency matching program. J Med Educ 1966;41(09):884-888

33 Graettinger JS. The residency matching program. Arch Otolaryngol 1978;104(11):615-619 